\title{
THE EFFECT OF YOUTUBE VIDEO ON STUDENTS' LISTENING COMPREHENSION PERFORMANCE
}

\author{
${ }^{\# 1}$ Siti Syafi'atul Qomariyah, ${ }^{* 2}$ Dira Permana, ${ }^{* 3}$ Heri Hidayatullah \\ ${ }^{\# 1}$ English Lecturer, FBMB, Universitas Pendidikan Mandalika, Indonesia \\ ${ }^{* 2}$ English Lecturer, FBMB, Universitas Pendidikan Mandalika, Indonesia \\ ${ }^{* 3}$ English Lecturer, FBMB, Universitas Pendidikan Mandalika, Indonesia
}

Corresponding Author Email: sitisyafiatulqomariyah@undikma.ac.id

\begin{abstract}
A B S T R A C T S
The difficulties to catch any intended information conveyed by speakers on the audio recording by the students still become problematic during learning listening comprehension in the classroom. This study aimed to find out the effect of applying YouTube videos on the students' listening comprehension performance. This study was experimental research (quasi-experimental with non-equivalent control group design). The researchers used all the first-semester students of English language education as a sample through the total sampling technique. To get the data, the researchers used a listening test as the instrument. There were two groups that were tested in the study; experimental and control groups. The experimental group was treated by applying YouTube videos while the control group was treated by Audio recording. Based on the result of the study, it was found that the t-test was 1.834 and the t-table was 0.073 (t-test was higher than t-table). In the other words, the alternative hypothesis was accepted and the null hypothesis was rejected. The result of the study also showed that the students felt more interested and motivated to learn listening comprehension by using YouTube videos as the learning media during the learning process takes place in the classroom. Thus, it could be concluded that the application of YouTube videos has given a positive and significant effect on students' listening comprehension performance.
\end{abstract}

\begin{tabular}{l}
\hline A R T I C L E I N F O \\
\hline Article History: \\
Received: May, 2021
\end{tabular}

Revised: May, 2021

Published: June, 2021

Keywords:
YouTube,
Listening Comprehension
Performance,

Keywords:

Performance,

How to cite: Qomariyah, S., Permana, D., \& Hidayatullah, H. (2021). The Effect of YouTube Video on Students' Listening Comprehension Performance. Jo-ELT (Journal of English Language Teaching) Fakultas Pendidikan Bahasa \& Seni Prodi Pendidikan Bahasa Inggris IKIP, 8(1), 67-73. doi:https://doi.org/10.33394/jo-elt.v8i1.3837

\section{INTRODUCTION}

The shift in the way of learning due to covid-19 pandemics all over the world nowadays has brought a significant effect on the implementation of Indonesia's education system. The fact that face-to-face learning was not in use anymore and changed into online learning. Online learning is a teaching and learning process that utilizes an internet connection and learning platform. Purbo (2002) stated that online learning is a form of information technology that is applied in the field of education in the form of virtual schools. Cisco (2001) explains the philosophical online learning as follows: (1) online learning is the delivery of information, communication, education, training online. (2) online learning provides a set of tools that can enrich the value of conventional learning (conventional learning models, studies of textbooks, CD-ROMs, and computer-based training) so that they 
can answer the challenges of the development of globalization. And on this occasion, the researchers had a chance to commit online learning following the rule set by the university responding to the education minister's instruction responding to covid-19 pandemics spread.

Upon conducting an observation, the researchers found that there were many students who were still difficult to catch the intended information such as finding the main idea of the spoken texts, predicting the detailed information of the speakers from the recording played, and differentiating variety of lexicons with sounds. These difficulties oftentimes made students look bored when asked to listen to the audio recording during the learning. Dealing with the problems above the researcher sought to find out the effect of applying YouTube on the students' listening comprehension ability. Listening is a process in which recognition of sounds, knowledge of lexicon, syntax, discourse markers, and the world all interact with each other (Bacon, 1989: 544). According to Rubin (1995), listening consists of processing information that listeners get from visual and auditory clues in order to define what is going on what the speakers are trying to express. Harmer (1998: 96) stated that one of the main reasons for getting students to listen and to speak English is to let them listen to different varieties and accents rather than just the voice of their teacher with its own idiosyncrasies.

There are two kinds of listening namely: 1) one-way listening (transactional listening); typically associated with the transfer of information, and 2) two-way listening (interactional listening); typically associated with maintaining social relations (Nation \& Newton, 2009: 37). The bottom-up process and Top-down process are part of the listening process. bottomup processing involves perceiving and parsing the speech stream at increasingly larger levels beginning with auditory-phonetic, phonemic, syllabic, lexica, syntactic, semantic, propositional, pragmatic, and interpretive (Field, 2003: 326). Top-down processes involve the listener in going from the whole-their prior knowledge and their content and rhetorical schemata to the part. In other words, the listener uses what they know of the context of communication to predict what the message will contain, and uses parts of the message to confirm, correct or add to this. The key process here is inferencing. Teaching listening means helping students to develop their listening skills and to understand the things they listen to (Richards, 2006). This could be created by using appropriate materials and media for learning sources and construct a good lesson plan. Through the use of materials and carefully designed activities, the goals of teaching listening are achievement (Etman, 2012).

There are many various teaching media as alternatives for teaching such as google classroom, moodle, blog, e-learning, i-tune, vimo, YouTube, etc. Among these alternative teaching media, YouTube is one of the most popular and attractive media to attract the learners' interest in learning. Youtube is a video-sharing website that allows users from over the world to watch videos posted by other users and upload videos of their own. Youtube content can be educational, entertaining, political, historical, medical, and personal videos. YouTube is a rich source of authentic materials especially in English lessons which could give motivate students to interact in an educational capacity through English language videos. YouTube, an important offshoot of digitalization, is leading the charge as the most multipurpose medium for content transactions in the classroom and outside the classroom. It not only provides digital entertainment but also provides a great environment for learning (Srinivasacharlu, 2020).

YouTube videos also could help students develop their learning autonomy levels as it encourages them to watch and explore English language videos continuously inside and outside classroom themes. YouTube videos are authentic in nature since it presents various interesting videos created by people from around the world which are not only designed for fun purposes but also for educational purposes. These videos could give students an opportunity to learn to communicate effectively in the foreign language by experiencing the language as it is used for real communication by native speakers (Rogers \& Madley, 1988). 
YouTube videos can offer many features as a teaching tool. As a free teaching resource, it can save an educational budget. It will also help students learn the English language in and out of the classroom; they can explore different English cultures with different accents. However, the two main advantages of using YouTube are authenticity and students' motivation. These two concepts could possibly be incorporated and enhanced by using YouTube.

There have been many kinds of research dealing with Youtube videos use in the learning of English as a foreign language, one of which was by Chia-ci et.al (2020) finding that the use of YouTube in the EFL classroom improved listening comprehension and retention of EFL college student. Further, Syafiq et.al (2021) found that YouTube videos as English learning material improved the speaking skill of students including their fluency, vocabulary, pronunciation, grammar, and content consisting of 85 students from the nonEnglish program. Even, Sari, et.al (2020) claimed that the video project provided EFL learners' the opportunity to improve themselves innovatively. Regarding these findings, the researcher feels interested to study more about the utilization of Youtube videos in the teaching of English, particularly in teaching listening skills. The intended question aimed to be sought within this study was whether or not Youtube videos give a significant effect on the students' listening comprehension performance.

\section{RESEARCH METHOD}

In this study, the researchers applied quasi-experimental with non-equivalent control group design. Sugiyono (2017: 116), writes that a Nonequivalent control group design is a design that includes two groups; experimental group and control group. Both the experimental group and control group had pre-test and post-test designs. The researchers gave different treatments to the two groups. The experimental group was treated by YouTube videos and the control group was treated by Audio recording. The population of this study was 90 students. The population is defined as a collection of all the possible objects, people, or scores of a particular type (Miller, 2005: 53). Regarding the total a number of population, the researchers took two classes as the samples; experimental and control group. To determine the samples of the study, the researchers used the total sampling technique due to all of the population were used. The research instrument used for data collection was a listening test. Willson (2008:170) writes there are many kinds of listening tests including text with the question (the learners have a list of multiple-choice questions in front of them while they listen to a text being read or a recorded dialogue). The researchers used this kind of listening test since it was commonly applied to the students. The listening test consisted of 35 questions in the form of multiple choice.

Data of the study were collected by firstly giving the same pre-test to both groups (experimental group and control group) before conducting the treatment. As the treatment was conducted, a post-test was subsequently administered to both groups. Data collected were then analyzed by using SPSS 19 and used t-test to compute the data derived from two samples. In identifying whether or not applying YouTube videos gave a significant effect on students' listening comprehension performance, the researchers compared the result of the ttest with $\mathrm{t}$-table. If the $\mathrm{t}$-test $\geq \mathrm{t}$-table, the alternative hypothesis would be accepted which means that applying YouTube videos gave a significant effect on students' listening comprehension performance. If the t-test $\leq \mathrm{t}$-table, the null hypothesis would be accepted which means that applying YouTube learning videos did not give a significant effect on the students' listening comprehension performance. 


\section{RESEARCH FINDINGS AND DISCUSSION Research Findings}

The result of the computing listening score of the experimental group and control group showed that the mean score of the experimental group was 75.3 and the control group was 73.2. The Median was 75 for both the experimental group and control group. The score of mode was 80 for the experimental group and 75 for the control group. The result of statistics in detail can be seen in table 1.

Tabel 1

Statistics

\begin{tabular}{|c|c|c|c|}
\hline & & $\begin{array}{l}\text { Experimental } \\
\text { group }\end{array}$ & $\begin{array}{l}\text { Control } \\
\text { group }\end{array}$ \\
\hline \multirow[t]{2}{*}{$\mathrm{N}$} & Valid & 45 & 45 \\
\hline & Missing & 0 & 0 \\
\hline \multicolumn{2}{|c|}{ Mean } & 75.3333 & 73.2222 \\
\hline \multicolumn{2}{|c|}{ Median } & 75.0000 & 75.0000 \\
\hline \multicolumn{2}{|c|}{ Mode } & 80.00 & 75.00 \\
\hline \multicolumn{2}{|c|}{ Sum } & 3390.00 & 3295.00 \\
\hline
\end{tabular}

To answer the hypothesis, the researchers analyzed the t-test by using SPSS. The result of the analysis can be seen in table 2 .

Tabel 2

T-test

\begin{tabular}{|c|c|c|c|c|c|c|c|c|}
\hline & \multicolumn{5}{|c|}{ Paired Differences } & \multirow[b]{3}{*}{$\mathrm{t}$} & \multirow[b]{3}{*}{ df } & \multirow{3}{*}{$\begin{array}{l}\text { Sig. }(2- \\
\text { tailed) }\end{array}$} \\
\hline & \multirow[b]{2}{*}{ Mean } & \multirow{2}{*}{$\begin{array}{c}\text { Std. } \\
\text { Deviation }\end{array}$} & \multirow{2}{*}{$\begin{array}{c}\text { Std. Error } \\
\text { Mean }\end{array}$} & \multicolumn{2}{|c|}{$\begin{array}{c}95 \% \text { Confidence } \\
\text { Interval of the } \\
\text { Difference }\end{array}$} & & & \\
\hline & & & & Lower & Upper & & & \\
\hline $\begin{array}{c}\text { Pair } 1 \text { Experimental - } \\
\text { Control }\end{array}$ & 2.11111 & 7.72311 & 1.15129 & -.20917 & 4.43139 & 1.834 & 44 & .073 \\
\hline
\end{tabular}

The result of testing the hypothesis showed that the t-test was 1.834 and the t-table was 0.073 at the significance level of 0.05 with the degree of freedom 44 . The score of the t-test was higher than the t-table $(1.834>0.073)$, which could be noted that the Null hypothesis $\left(\mathrm{H}_{\mathrm{o}}\right)$, which stated: "There is no significant effect of applying YouTube videos on the students' listening comprehension performance", was rejected. Therefore, the Alternative hypothesis $\left(\mathrm{H}_{\mathrm{a}}\right)$, which stated: "There is a significant effect of applying YouTube learning videos on the students' listening comprehension performance", was accepted.

During the process of applying the treatment, the students showed interest and motivation in the media used. The students could show maximum effort to identify various words, understand the meaning of the words, enunciate the words. Youtube learning videos provided both audio and visual inputs to the students which attracted and gave students the 
opportunity to figure out the speech or words they heard within the learning process as well as to enhance their language abilities.

\section{Discussion}

The research problem of this study is: Is there any significant effect of applying YouTube learning videos on students' listening comprehension performance?

After computing all data of findings, the researcher could answer the intended question above. The result of the finding showed that alternative hypothesis meaning that there was a significant effect of applying Youtube videos on students' listening comprehension performance was accepted. This finding was established by statistical computation score showing that t-test was higher than t-table $(1.834>0.073)$. During the treatment, the application of Youtube videos made the students feel easier and fun to learn listening comprehension in the classroom. Even though teaching with Youtube videos uses gave positive, some students still found difficulty in learning some listening materials. The reason why some of the students felt difficulty due to listening skill was undeniably difficult than other skills.

Willson (2008: 13) states that (1) characteristics of the message; linguistic difficulties include unknown words, lexical density (short spaces of time between content words, forcing the listener to concentrate harder), and complex grammatical structures. Non-linguistic characteristics of the message include familiarity with the topic, text type, and cultural accessibility. (2) Characteristics of the delivery; it is a vital factor. There are two kinds of vital factors namely reciprocal (there is the interaction between two or more people/ there is a conversation) and nonreciprocal (the listener has the opportunity to contribute to a conversation). Nonreciprocal is more difficult than reciprocal. (3) Characteristics of the listener; some students have problems motivating themselves to listen. According to multiple intelligences theory, people possess different bits of intelligence such as linguistic, logicalmathematical, spatial, bodily kinaesthetic, musical, interpersonal, and naturalist. Besides that the students' dispositions, there is the age factor. Young learners can be loosely categorized as anything from the age of seven or eight up to those in their mid to late teens. Some temporary characteristics that affect listening might include anxiety, tiredness, boredom, or having a cold. (4) Characteristics of the environment; environmental conditions which may affect listening performance include the temperature of the room, background noise, or defective equipment which affects the clarity of a recording.

However, the success of applying Youtube videos could be seen from the students of the experimental group which was more enjoyable and fascinated to learn listening materials presented during the learning compared to the students treated by audio recording. The students even looked more motivated to follow up the lecturer's instruction dealing with the accomplishment of the task. The use of YouTube videos provided an opportunity for the students to learn the English language as if they were confronted with native speakers directly in a settled setting where the learning took place. The finding of the study was also similar to what had been studied by Ayu (2016) entitled "YouTube Videos in Teaching Listening". The result of her study showed that YouTube is a learning website in which the teacher could take authentic teaching materials. Students were more likely to enjoy the learning activity through YouTube because the use of Youtube videos attracted their attention. She added that Youtube videos help learners get a better insight into the subject lesson through visual support. Students certainly gain knowledge as well as listening skills because YouTube video makes the learning situation in the classroom more enjoyable, motivating, interesting, creative, cooperative, and productive. The students tended to be excited to complete the task given by the teacher when this media was applied. 
Rizkan et.al (2018) also conducted the effect of using YouTube videos as the teaching media on the students' listening skills (the case of second-semester students of English education study program of IKIP PGRI Pontianak). He found that youtube was more effective than using audio to teach listening comprehension and there was an interaction between the teaching materials in listening comprehension. These results have established the finding of the study that Youtube videos succeed to give a significant effect on students' listening comprehension performance during the learning.

\section{CONCLUSION}

Learning English through applying YouTube with relevant videos has become one of the alternatives or main sources of learning within the improvement of English students' listening comprehension performance. The English learning videos provided by Youtube present illustrative images in which the students can learn the materials through visual and audio aids. Youtube learning videos also provide the students with large areas of self-learning and provision of knowledge based on the students' curiosity. On the other hand, other learning sources where knowledge and goals are limited as well as time and place limit the students' mobility in exploring their intellectual capacity. The data analysis proves that applying YouTube learning videos for students of the English language department, particularly the first semester of experimented students has indeed enhanced their listening comprehension performance after watching YouTube videos better than students treated without Youtube videos of learning; Audio recording. The statistical result also shows that there is a significant effect of the students' listening comprehension performance scores between the experimental and control class, in which t-test is higher than t-table in significance level 0.5. For further results on the study of Youtube, the next researchers can commit the same study with different fields of study and topics for digging up the hidden strength of Youtube as the source of learning English.

\section{REFERENCES}

Ayu, L. P. (2016). YouTube Videos in Teaching Listening: The Benefits in Experts' Views. Research and English Education (READ), 1(2), 152-160.

Bacon, S. (1989). Listening for Real in the Foreign Language Classroom. Foreign Language Annal, 22:543-550.

Chien, C., Huang, Y., \& Huang, P. (2020). YouTube Videos on EFL College Students' Listening Comprehension. English Language Teaching, 13(6), 96-103. https://doi.org/10.5539/elt.v13n6p96.

Cisco (2001). E-learning: Combines Communication, Education, Information, and Training. Avaliabe at [Online] http://www.cisco.com/warp/public/10/wwtraining.

Etman, D. (2012). Teaching Listening. Jakarta: Kementerian Pendidikan dan Kebudayaan.

Field, J. (2003). Promoting perception: lexical segmentation in L2 listening. ELT Journal, 57(4), 325-334.

Harmer, J. (1998). How to teach English. NY: Longman ELT.

Miller, S. (2005). Experimental Design and Statistics (2nd Ed). Taylor \& New York: Francis e-Library.

Nation, I. S. P., \& Newton, J. (2009). Teaching ESL/EFL Listening and Speaking. Routledge, New York and London,

Purbo, O. W. (2002). Buku Pintar Internet Teknologi E-Learning berbasis PHP dan Mysql Merencanakan dan Mengimplementasikan Sistem E-Learning. Jakarta. Elex Media Komputindo.

Richards, J. C. (2006). Communicative Language Teaching Today. New York: Cambridge University Press. 
Rizkan, A. M., Mukhaiyar., \& Refnaldi. (2018). The Effect of Using YouTube as a Teaching Media on the Students' Listening Skill (The Case of 2nd Semester Students of English Education Study Program of IKIP PGRI Pontianak). Advance in Social Science, Education and Humanities Research. Seven International Conference on Language and Arts (ICLA), 301, 286-290. https://dx.doi.org/10.2991/icla-18.2019.48.

Rogers, C., \& Medley, F. (1988). Language with a Purpose: Using Authentic Materials in the Foreign Language Classroom. Foreign Language Annals, 21(5), 467-478.

Rubin, J. (1995). The Contribution of Video to the Development of Competence in Listening, in Mendelsohn, D and Rubin J (EDS) A Guide for the Teaching of Second Language Listening, San Diego: Dominie Press, 151-165.

Sari, A. B. P., Dardjito, H., \& Azizah, D. M. (2020). EFL Students' Improvement through the Reflective YouTube Video Project. International Journal of Instruction, 13(4), 393408.https://doi.org/10.29333/iji.2020.13425a.

Srinivasacharlu, A. (2020). Using Youtube in Colleges of Education. Shanlax International Journal of Education, vol. 8, no. 2, 2020, pp. 21-24. DOI: https://doi.org/10.34293/education.v8i2.1736

Sugiyono. (2017). Metode Penelitian Kuantitatif dan Kualitatif R\&D. Bandung: Alfabeta.

Syafiq, A. N., Rahmawati, A., Anwari, A., \& Oktaviana, T. (2021). Increasing Speaking Skill through YouTube Video as English Learning Material during Online Learning in Pandemic Covid-19. Elsya : Journal of English Language Studies, 3(1), 50-55. https://doi.org/10.31849/elsya.v3i1.6206.

Willson, J. J. (2008). How to Teach Listening. Pearson Education Limited: England. 